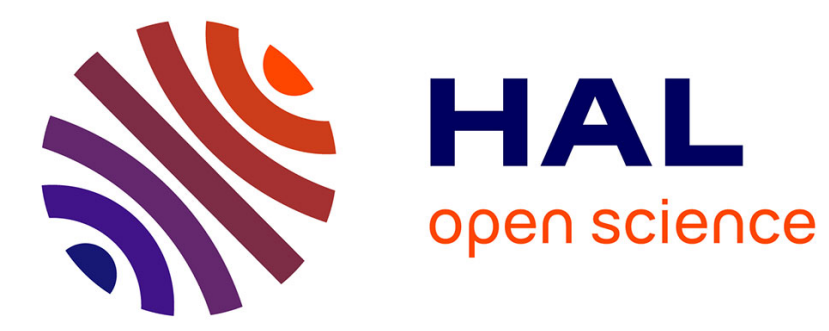

\title{
Andrew Schmitz and William H. Meyers (eds) (2015) Transition to Agricultural Market Economies - The Future of Kazakhstan, Russia and Ukraine, CAB International, Wallingford, U.K., $258 \mathrm{p}$
}

\author{
Ulrich Koester
}

\section{To cite this version:}

Ulrich Koester. Andrew Schmitz and William H. Meyers (eds) (2015) Transition to Agricultural Market Economies - The Future of Kazakhstan, Russia and Ukraine, CAB International, Wallingford, U.K., 258 p. Review of Agricultural, Food and Environmental Studies, 2016, 97 (3), pp.203-206. 10.1007/s41130-016-0015-4 . hal-03114830

\author{
HAL Id: hal-03114830 \\ https://hal.science/hal-03114830
}

Submitted on 19 Jan 2021

HAL is a multi-disciplinary open access archive for the deposit and dissemination of scientific research documents, whether they are published or not. The documents may come from teaching and research institutions in France or abroad, or from public or private research centers.
L'archive ouverte pluridisciplinaire HAL, est destinée au dépôt et à la diffusion de documents scientifiques de niveau recherche, publiés ou non, émanant des établissements d'enseignement et de recherche français ou étrangers, des laboratoires publics ou privés. 


\title{
Andrew Schmitz and William H. Meyers (eds) (2015) Transition to Agricultural Market Economies - The Future of Kazakhstan, Russia and Ukraine, CAB International, Wallingford, U.K., 258 p
}

\author{
Ulrich Koester $^{1,2}$
}

Published online: 29 March 2016

(C) INRA and Springer-Verlag France 2016

The topic of the book is of great interest. There is hope that countries which have not yet used their agricultural resources efficiently may be able to increase agricultural efficiency and contribute to a large extent to world food security. The two reputed editors of the book motivated 44 authors to write 23 contributions on the present agricultural situation in those countries that may be able to exploit their so far unused production potential. "The evolutions of supply capacities in major food exporting countries and the short- and long-term policies and investments that affect these countries' supply are very relevant when assessing global food market prospects in the coming years and decades. Among the major grainexporting countries, the Kazakhstan, Russia and Ukraine (KRU) region has become a major player in the global food market. Between 2006 and 2012, the KRU region contributed $14 \%$ of total world grain exports and $21 \%$ of world exports of wheat. Furthermore, the US Department of Agriculture (USDA) projects that by 2021, the KRU region's share in total world grain and wheat exports will rise to $22 \%$ and $29 \%$, respectively. The KRU region has the potential to expand grain production by increasing both grain area and yields." (Feder 2015).

The countries under consideration are special with respect to their economic and agricultural performance. Two of them (Russia and Ukraine) still produce a GDP that is less than their GDP in 1990 and far less than the performance of the 33 transition countries that are under scrutiny by the European

Ulrich Koester

ukoester@ae.uni-kiel.de

University of Kiel, Kiel, Germany

2 Leibniz Institute of Agricultural Development in Transition Economies, IAMO, Halle, Germany
Bank for Reconstruction and Development (EBRD 2012) (Transition Report 2011). Only oil-rich Kazakhstan managed to surpass the 1990 GDP in 2007 and had adjusted to the average performance of the 33 transition countries. Concerning agricultural production, all three countries lag behind their performance in 1990. Hence, one may wonder why the western economists assumed planned economies were inefficient, but have not yet been able to improve as expected. Having this in mind, readers will be eager to study this book.

The editors structured the book into five parts with topics closely related with respect to the topics examined in the individual contributions. Part 1 contains the following chapters.

The first chapter on "Overview of Agriculture in Kazakhstan, Russia and Ukraine" and the third chapter on "The Rise of the Former Soviet Union Region as a Major Grain Exporter" are authored by William W. Liefert and Olga Liefert. The authors present an overview of the three countries under consideration. It is clearly explained that in spite of the decline in grain production in the three countries from 1987 to 1991 and 2006 to 2012, grain trade has changed from large imports in the period from 1987 to 1991 to significant exports in the middle of the 1990s. The change in the trade position was made possible due to the large decline in domestic use of feed grain. Farms have not been able to adjust in the direction of comparative advantage. The form of privatization, insecure property rights, high uncertainty due to policy interventions, and lack of human capital trained for decision-making in a market economy constrained adjustment of the individual farms in line with international competitiveness. The data clearly show that the three countries have not yet exploited their grain production potential; hence, grain production will likely grow. Nevertheless, projection of exports is not easy. The development depends not only on the efficiency gains in the grain sector but also on changes in the milk and meat sectors. The progress in creating an enabling 
environment for a market economy will be crucial for the export potential of grains.

The second chapter on "Kazakhstan's Agricultural Development Constraints: Evidence from the Wheat, Beef and Dairy Sectors" by Martin Petrick and Dauren Oshakbaev is the only chapter in the book which focuses on Kazakhstan. The authors support the general view that "Kazakhstan is regarded widely as a key player on world agricultural markets, with considerable export potential in the wheat, beef and dairy sectors" (page 24). It is somewhat surprising that the authors found that farm managers see the lack of available land as the main constraint to land expansion. Obviously, prices are not allowed to adjust demand to the availability of land.

The fourth chapter, titled "Policy Issues and Prospects for Ukraine's Grain Exports," is written by Kateryna G. Schroeder and William H. Meyers. The chapter is highly informative for readers who want to get acquainted with the policy determinants of Ukrainian grain exports. External protection and policy-induced transaction costs are of key importance. "The meat, dairy and sugar industries receive positive support, while the grain industry receives negative support" (page 42). The still strongly regulated land market is a main obstacle for increasing efficiency in Ukrainian agriculture and in the grain economy in particular.

The fifth chapter on "Ukrainian Wheat Export Development" by Iryna Kobuta clearly identifies the main determinants for export growth of wheat: decline in domestic use, improvement of the Ukrainian export development infrastructure and export restrictions. Ukrainian agriculture and particularly the wheat economy were highly taxed in some years, increasing the variability in profit rates of wheat production. Consequently, Ukrainian wheat exports grew significantly over time but also wildly fluctuated. Thus, Ukraine is not a reliable supplier of wheat on the international markets. The author may have conveyed additional information on the effects of the exchange rate regime on wheat production in Ukraine. Overvaluation was extremely high in some years and heavily contributed to the taxation of the agricultural sector.

Chapter 6 on the "Effect of Relative Export Price Changes of the Top Principal Crops in Russia" by Ekaterina Vorotnikova, Serhat Asci and James L. Seale, Jr. presents an overview of the relative export price changes of the top principal crops in Russia from 1992 to 2011. In addition, the authors applied a model to calculate output price and land elasticities based on the same period. It is however questionable whether price series data-which are highly heterogeneous with respect to price incentives, policy interventions and exchange rate instability - can be used for calculating elasticities. Their conclusion is that " $[\mathrm{b}]$ ased on the full assessment of all results, we can confirm that wheat is still considered the major crop for Russia, just as maize is the major crop for the USA" (page 69).
Part II of the book includes seven chapters.

This reviewer read with most interest the chapters on cooperatives. These chapters are the only ones in the book that mention the causes for the existence of production cooperatives (chapter 7: "The Role of Production Cooperatives in Russian Agriculture" by Svetlana Golovina, Jerker Nilsson and Axel Wolz) and service cooperatives (chapter 8, "Agricultural Cooperative Development in Kazakhstan and Ukraine" by David Sedik and Zvi Lerman). The chapters emphasized that production cooperatives in Russia came into existence as a rational choice of members, taking into consideration the absence of better alternatives partly due to the lack of enabling environment and the dearth of entrepreneurship. These determinants explain the resistance to change of the cooperatives and, thus, the slow adjustment progress.

Sedik and Lerman investigate the opportunities for service cooperatives. The authors argue convincingly that the establishment of such cooperatives may suffer from citizens' past experience with the socialist version of cooperation. Moreover, in the special case of Ukraine, small- and medium-sized farmers may react to disincentives due to tax regulation for cooperation. The authors conclude that " $[\mathrm{w}]$ hile the governments publicly recognize the usefulness of cooperatives, policies designed to support them focus on input purchase subsidies and subsidized loans. While these policies have helped some, they also seem to have bred a class of false cooperatives, established only for the purpose of gaining access to subsidized credits and inputs with no regard for true cooperative principles" (page 90).

Epstein raises a very important topic in chapter 9, "The Strategy of Innovative Development of Russian Agriculture". He states that "the national project on developing agribusiness in Russia addresses the challenge of increasing investments through subsidizing loans but does nothing to facilitate innovative development" (page 92). The question is what the government could do to promote innovation. Epstein presents a figure where he adroitly structures the determinants of innovations. However, some of his conclusion may not be supported by everyone, such as "Russia should (i) ensure more accessible loan financing agricultural and food producers; (ii) increase government support for agriculture to a level that would guarantee the profitability necessary for sustainable production growth; and (iii) amend the federal governing status of the cities of Moscow and St. Petersburg to permit them to provide budgetary support to agricultural producers of their respective oblasts in such amounts as necessary for the sustainable provision of food products to these cities" (page 98). These recommendations do not support a market orientation of agriculture.

Chapter 10, titled "The Emergence of Agroholdings and Patterns of Land Use in Ukraine" by Volodymyr Lapa, Taras Gagalyuk and Igor Ostapchuk, deals with another specifics of agricultural development in many former planned economies, 
the move to extremely large companies nearly unknown in market economies. The 78 largest enterprises, each larger than 10,000 ha, already cultivated about $26 \%$ of total crop land in 2012. It is unknown whether this development was mainly driven by pure market forces or primarily stimulated by the institutional environment. The authors considered land market regulations, including the form of privatization at the beginning of the transition period and restricted land transfer regulation, as the most important determinants.

Chapter 11, titled "Large-Scale Dairy and Poultry Production in Russia: Level and Trends of Development" by Vladimir N. Surovtsev, Yulia Nikulina and Uliana Saigusheva, analyzes a new worldwide experience: the establishment of prodigious enterprises in dairy and poultry production born from significant governmental support. The aim of the government is to stimulate production growth and make these farms more competitive compared to small farmers. Data clearly show that production has increased and the share of household production in total production of these products has declined. The authors also state that these enterprises introduced new technologies and improved the quality of the product. However, it is still open for debate whether these facilities are competitive without government support.

Konstantin Hahlbrock and Heinrich Hockmann contributed chapter 12, titled "Does Agroholding Membership Increase Productivity and Efficiency in Russian Agriculture? Evidence from Agroholdings in the Belgorod Oblast". The authors investigate empirically whether agroholdings increase productivity and efficiency in Russian agriculture. They confirm the question in contrast to some other studies. However, they state, "It is uncertain whether this issue is related to transaction costs or whether it represents a needed challenge for Russian agriculture" (page 123). This is a critically important statement that reminds the reader that projections based on empirical work have to assume that the economic environment will not change in the future. However, there is widely held agreement that enabling conditions have to be improved; hence, the economic environment will change.

Chapter 13, written by Vladimir N. Surovtsev, Evgeny Schedrin, Mikhail Ponomarev, Elena Chastikova and Uliana Saigusheva, covers the "Large-scale Dairy and Poultry Production in Russia: Efficiency and External Environment". The authors provide data on profit margins for products sold, including industrial processing. These margins are based on the prime costs of product and selling prices. Unfortunately, we do not know how the prime costs were calculated. These margins likely do not inform on the return on capital and thus on the profitability of investments. Furthermore, average costs and margins hide the variance in costs and selling prices and, as a result, do not inform on profitability of the marginal producer. The authors emphasize an important point: The presented calculations do not include the environmental effects, which are highly negative in some regions. Consequently, the social return on investment in these large production facilities is certainly significantly lower than the private one.

Part III of the book includes two chapters. Chapter 14, authored by Charles B. Moss and Andrew Schmitz, deals with "International Crop Yield Comparisons: Selected KRU". Chapter 15, titled "Modelling Fertilizer Demand: The Three Bads", was written by Andrew Schmitz and Charles B. Moss.

The authors look into some specifics of wheat production in the KRU region and compare that region with wheat production in selected US Great Plains regions in chapter 14. The data reveal some surprises. One might have expected that wheat yields in Kazakhstan, Russia and Ukraine had significantly increased over time since 1990. Strangely enough, even in Ukraine, which boasts the world's best soil and climate for wheat production, the trend of production is statistically not significant. Another surprise concerns the wheat production and wheat exports of Kazakhstan. One may wonder whether a landlocked country with such low yields of wheat will be a sustainable exporter of wheat in the future. One main finding presented in chapter 15 concerns fertilizer use in the three countries. The authors observe that fertilizer use is low, but they cannot support the view that fertilizer application is suboptimal given the present equipment and seeds available in these countries.

Part IV includes the following chapters.

Vasily Erokhin presents in chapter 16, "Russian Trade in Agricultural Products: Current State and Influences of Trade Integration", data on Russian exports and imports of selected agricultural products and analytical support of agriculture. $\mathrm{He}$ finds that - based on OECD data-Russian agriculture is less protected than agriculture in selected OECD countries. However, the figures do not include the effect of overvalued exchange rates in some periods and the effect of specific regulations - including land markets - which in addition to the mentioned causes suppressed development of Russian agriculture.

Lars Brink contributed chapter 17: "Farm Support in Ukraine and Russia under the Rules of the WTO”. Brink reveals the impact of WTO rules on agriculture in Russia, which became a WTO member in 2012, and in Ukraine, which became a WTO member in 2008. He concludes that both countries support agriculture less than agreed by the WTO and will have no problem staying within the bounds of AMS in the near future, but continuing policies as over the last years may generate problems in 2018 and beyond.

In chapter 18, "Accession of KRU to the WTO: The Effect of Tariff Reductions on KRU and International Wheat Markets", Saule Burkitbayeva and William A. Kerr investigate the recent development of trade by the three countries. The focus of the chapter is on the application of a global simulation model aimed at quantifying the liberalization effects of WTO membership on these three countries as well as 
on Canada, EU (27) and the USA. The calculations are based on supply elasticities of 1.5 for all countries. However, it may well be that WTO membership will not only lead to a movement along the supply curve of wheat but also to a shift of the supply curve either due to changes in relative prices or reduced transaction costs. In such case, the actual positive welfare effects for the three countries might be higher than calculated, and the negative effects for the other countries might also be higher than calculated.

Authors Linde Götz, Ivan Djuric and Thomas Glauben contributed chapter 19, titled "Wheat Export Restrictions in Kazakhstan, Russia and Ukraine: Impact on Prices along the Wheat-to-Bread Supply". The empirical analysis is based on a sound economic model. The findings mainly support the stated hypotheses. However, the actual impact on prices of either the expectations of stockholders or illegal trade is beyond those predicted by their model. The result of the study should motivate policymakers in the countries under consideration to institute more targeted policy measures as social safety net policies.

Part V contains four chapters:

Two chapters address land issues, which are crucial for agricultural development. Olga Murova (chapter 20) studies "Agricultural Land Policy of Ukraine: State Legislation and Efficiency Analysis". She emphasizes the importance of having a reliable cadastral as a precondition for liberalizing the land markets. The chapter is essential for the reader who has not yet been acquainted with the development of land market regulations in Ukraine up to 2010. In the meantime, there have been some changes that are not dealt with in the chapter. That certainly holds true for the land rental price, which has been quoted from a paper published in 2006.

Chapter 21, authored by Denys Nizalov, Suzanne Thornsbury, Scott Loveridge, Mollie Woods and Olha Zadorozhna, looks into "The Dynamics of Agricultural Production and Land Use in Post-Soviet Ukraine". It starts with a description of the changes in the agricultural sector pertaining to total agricultural output by the different types of farms. The most striking changes occurred in the production of household farms. These small farms are the only types of farm categories which managed to expand their share in the production of different agricultural products largely above the level in 1990; moreover, it is the only type of farm which increased the total amount of crop production significantly since 1990 , by more than $150 \%$. One may wonder how this development could be achieved. Are the statistical data really correct? Are feed, fertilizer and other services used by the household plots bought at market prices? If these facts could be confirmed, the experience of the household plots is a strong indicator of the powerful effects of incentives.

Marlene Boersch and Sandra Kirby contributed chapter 22 on "Competitive Analysis of Pulse Production in Russia,
Ukraine and Kazakhstan". In the first part of the chapter, the reader receives an overview on the agricultural situation in the three countries. The data may not be representative of the current situation because they are based on 2011 or 2012. Nevertheless, some of these figures raise surprises, e.g. fertilizer application per hectare arable land was $16 \mathrm{~kg}$ in Russia, $30 \mathrm{~kg}$ in Ukraine and only $2 \mathrm{~kg}$ in Kazakhstan in 2011. Related cereal yields per hectare were 2282, 3000 and $1200 \mathrm{~kg}$ in the same year. These figures lead the reader to wonder how producers in Kazakhstan survive with such low yields in cereals. Country-specific data for 2012 reveal that the difference between yields in specific cereals, e.g. spring wheat, do not as much differ in 2012 as in 2011 between Kazakhstan and the other two countries. It seems to be a problem to use data only from one specific year if the variance across time is high in particular for Kazakhstan. The same argument holds for the presentation and comparison of production costs for one selected year.

The book concludes with chapter 23, "Evaluating the Economic Efficiency of Subsidies Based on the Basic Output Equations for Agricultural Enterprises in the Northwestern Regions of Russia", by David Epstein. Epstein breaks new ground here. He aims at identifying the impact of subsidies on agricultural production and employs an econometric approach. After having estimated a Cobb-Douglas production function in a traditional way, he introduces subsidies paid to enterprises as an additional factor of production. This procedure may need some discussion. A surprising revelation of the chapter is that according to the regression analysis, land had a negative effect on production.

This book should attract agricultural economists generally interested in the development of agriculture in transition countries in spite of the focus on only four countries. Those researchers and businessmen who want to settle in these countries are well advised to read this book. The book not only informs readers on data and select policy issues, in particular the land market, but it may also help design new research initiated by some surprises presented in the book as well as some neglected issues, in particular a more in-depth analysis of the impact of institutions, including corruption and administrative problems on the agricultural sector.

\section{References}

Feder G. (2015) Foreword, in: Transition to Agricultural Market Economies: The Future of Kazakhstan, Russia and Ukraine, CAB International, Wallingford, U.K., P. xiii

EBRD (2012) Transition Report 2011, Crisis and Transition: The people's perspectives, London, U.K., $182 \mathrm{p}$ 